\title{
THE GIST OF THE WORLD CUSTOMS ORGANIZATION
}

\author{
Serhii M. Perepolkin \\ Department of International Law, Educational Scientific Institute of Law and International Legal Relations, \\ University of Customs and Finance, \\ 2/4 Vladimir Vernadsky Str., Dnipro, Ukraine, 49000 \\ https://orcid.org/0000-0003-2914-5898 \\ psm-13@ukr.net \\ Polina V. Trostianska \\ Student of Educational Scientific Institute of Law and International Legal Relations, \\ University of Customs and Finance, \\ 2/4 Vladimir Vernadsky Str., Dnipro, Ukraine, 49000 \\ https://orcid.org/0000-0001-7562-633X \\ ganza1313@gmail.com
}

\begin{abstract}
In this article there is for the first time offered a theoretical justification for understanding the purpose (goals), tasks and functions of the World Customs Organization as interrelated categories. Emphasis is placed on the fact that the explanation of the essence of any international organization should begin with a description of its purpose (goals), objectives and functions. The position of the authors was formed taking into account the results of the generalization of doctrinal approaches of scientists to understand the essence of the World Customs Organization. Particular attention was paid to the characteristics of the provisions of the Convention establishing the Customs Cooperation Council of December 15,1950 , which is a constituent act of the World Customs Organization, as well as other international conventions, resolutions, declarations and recommendations adopted by this organization. It is emphasized that in contrast to the list of functions of the organization were specified in Art. III of the Convention establishing the Customs Cooperation Council of December 15, 1950, in its text there is no clear and unambiguous statement of the purpose (goals) and objectives of WCO.

As a result of the study, the authors note that the purpose of WCO determines the desired result, the achievement of which should be aimed at the activities of the organization and is to promote cooperation between the governments of its members. And the achievement of this goal necessitates the solution of common tasks for WCO members, which specify the purpose of the organization. It was also investigated that the WCO objectives provided for in the Preamble to the Convention on the Establishment of Customs Cooperation Council do not exhaust their full list, the gradual expansion of which takes place through the adoption of legal acts by the WCO Council. It is also determined that objectives of WCO are subordinated to the functions of WCO.
\end{abstract}


Keywords: international organizations, international customs law, international customs cooper-ation, international conventions, Customs Cooperation Council, World Customs Organization.

\section{INTRODUCTION}

The essence of any international organization is expressed in its purpose (goals), tasks and functions, which are closely interrelated. In view of this, to ensure the effective operation of an international organization, its goals (objectives), tasks and functions the founding member states usually reflect in the constituent act of the organization in the form of clearly defined, exhaustive lists. The accuracy of their presentation eliminates the risks of conflicts of interest between the organization and its member states, helps to correctly define the boundaries of the legal personality of the international organization, audit its performance and forecast the prospects for its further development. The accuracy of the statement of the purpose (goals), tasks and functions of the international organization in its constituent act and the unambiguity of their interpretation by the representatives of legal doctrine is also important for conducting research on the legal status and activities of the international organization. Therefore, the need to focus primarily on the goals (objectives), tasks and functions of international organizations in the disclosure of their essence has repeatedly being emphasized by the researchers of activities of international organizations from different countries (Moravetsky, 1976; Scharf, 2007; Schermers and Blokker, 2011).

Various theoretical and applied aspects of the World Customs Organization (WCO) activity have repeatedly been the subject of scientific research. After all, today the WCO represents 183 Customs administrations across the globe that collectively process approximately $98 \%$ of world trade. As the global centre of Customs expertise, the WCO is the only international organization with competence in Customs matters and can rightly call itself the voice of the international Customs community.

Most often, scholars have analyzed the practical issues of its interaction with the World Trade Organization and national customs administrations to promote trade (Kafeero, 2008; Cheng, 2010; Weerth, 2020), in particular in the areas of determining the rules of origin of goods, customs valuation, nomenclature and trade facilitation, combating customs offenses, etc. (Wolffgang and Dallimor, 2012).

Scholars have often been drawn to the applied aspects of the application of international conventions developed by WCO at the international and domestic levels of legal regulation of customs relations. Among such conventions, the provisions of the Convention on the Simplification and Harmonization of Customs Procedures of May 18, 1973 (Kafeero, 2009; Denisenko, 2015), the Convention on the Harmonized Commodity Description and Coding System of June 14, 1983 (Weerth, 2008), Convention on temporary importation of June 26, 1990 (Raykova, 2009) were most frequently analyzed.

The activity of the internal system of representative (Council, Finance Committee and General Political Commission), executive (committees, subcommittees and various working groups, which are divided into four groups depending on the subject of activity: on the tariff 
and trade issues (Harmonized System Committee, Scientific Subcommittee, Harmonized System Review Subcommittee, Harmonized System Working Group, Technical Committee on Rules of Origin, Technical Committee on Customs Valuation, Transfer Pricing Focus Group), on procedures and facilitation (Standing Technical Committee; Revised Kyoto Convention Committee; Istanbul Convention Administrative Committee; ATA Contracting Parties; Information Management Subcommittee;); on enforcement and abidance (WCO Counterfeiting and Piracy Unit (CAP); Executive Committee; Global Information and Intelligence Strategy Project Group; Commercial Fraud Working Group; Electronic Crime Expert Group); on capacity building (Capacity Building Committee; Integrity Subcommittee) and the WCO Administrative Body (General Secretariat) (Weerth, 2009; Grebennikov, A.V.) (2012).

The interaction of WCO with other international intergovernmental and international non-governmental organizations was studied within the dissertation research „Legal status of the World Customs Organization" by a scientist from Ukraine Ya.I. Muzyka (2015).

At the same time, the scope of WCO's activities is much broader, which leads to research on the results and prospects of its activities on other issues, including the introduction of innovative technologies in the organization in the context of COVID-19 (Chapa, 2020), training and retraining of national customs administrations (Hesketh, 2020), use and dissemination of accumulated knowledge among all interested participants in international customs relations (Peteva, 2020).

Note that despite the fact that the subject area of research on the activities of WCO is quite diverse, a common feature of many of them is a reference to the purpose (goals), objectives and functions of this organization. In most cases, scientists do not characterize these categories and do not reveal the relationship between them. There are also many examples where the purpose, tasks and functions of WCO are identified or arbitrarily interpreted without regard to the logical connection between them. Therefore, in view of the above, the article offers an author's interpretation of the purpose (objectives), tasks and functions of WCO, which in interrelation characterize the essence of this organization and serve as the basis of its legal personality as a subject of international customs law.

\section{MATERIALS AND METHODS}

Achieving the goal of the paper stipulated the necessity to use various methods of scientific cognition, among them there are: historical and legal method; comparative method; method of analysis; synthesis method; method of generalization. The study of the issue was conducted in three stages.

At the first stage, a theoretical analysis of existing in the legal scientific literature methodological approaches to understanding the purpose (goals), objectives and functions of WCO. Particular attention is paid to the processing of the provisions of the Convention establishing the Customs Cooperation Council of December 15, 1950, which is the constituent act of WCO, as well as other international conventions, resolutions, declarations and recommendations adopted by this organization. 
In the second stage, based on the results of generalization of doctrinal approaches to understanding the purpose (objectives), tasks and functions of WCO, as well as the provisions of international conventions and acts adopted by this organization, the author's approach to the interpretation of the scientific categories studied in the article is developed and argued.

\section{RESULTS AND DISCUSSION}

Immediately after the end of the Second World War, European states began to actively develop cooperation in various areas of international relations. International cooperation on customs issues or international customs cooperation was chosen as one of such directions. One of the first steps in this direction was the creation by thirteen European states in 1948, in the structure of the Committee for European Economic Cooperation, founded in 1947, the Customs Committee for the comparative study of various aspects of customs. The latter's tasks included, in particular, comparing customs procedures in the member states of the Committee for Standardization of These Procedures, developing a common product nomenclature, adopting common rules for valuing goods for customs purposes, and determining the possibility of forming one or more European customs unions.

The result of the work of the Customs Committee on December 15, 1950 was the signing of three international conventions: the Convention on Nomenclature for the Classification of Goods under Customs Tariffs (entered into force on September 11,1953), the Convention on the Valuation of Goods for Customs Purposes (entered into force on June 28, 1953) and the Convention establishing the Customs Cooperation Council (entered into force on November 4, 1952).

From the outset, on the basis of the Convention establishing a Customs Cooperation Council of 15 December 1950, it was planned to establish a European regional customs organization whose task would be to interpret and apply the two previous conventions. It was in this format that on January 26, 1953, with the participation of seventeen European states, the founding session of the newly formed international organization took place. However, later on, states from other geographical regions of the world also began to show interest in the activities of the Customs Cooperation Council.

As a result, this led to a significant expansion of the member states of the organization and the introduction in 1994 of its unofficial name „World Customs Organization”. As the range of WCO Member States increased, approaches to interpreting its purpose, objectives and functions evolved. However, a comprehensive scientific study of these categories has not been conducted to date. In view of the above, the article proposes an author's interpretation of their essence as interrelated concepts that together characterize the essence of WCO.

As a result of elaboration of the provisions of the Convention on the Establishment of the Customs Cooperation Council of December 15, 1950 (Convention on the Establishment of the CCC), it should be noted that its text lacks a clear and unambiguous statement of the purpose and objectives of WCO. The exception in this regard is Art. III of the Convention, the text of which enshrines a list of functions of the organization, which scientists often characterize as exhaustive (World Customs Organization, 1950). 
Based on the thesis that the essence of WCO is expressed in its purpose (objectives), tasks and functions, which are closely interrelated, their characteristics are proposed to begin with the disclosure of doctrinal approaches to understanding the purpose (objectives) of WCO, which scientists interpret differently.

G.-M. Wolfgang, K. Delimour (2012) and T. Matsudaira (2007) believe that the main goal (mission) of WCO is to increase the efficiency and effectiveness of the customs administrations of its member states around the world.

V.V. Mytsyk (1991) does not mention the purpose of establishing WCO at all, replacing it with the author's wording of the main purpose of the Convention on the Establishment of the CCC, namely: «the most complete harmonization of customs systems of its participants, development and improvement of customs equipment, customs legislation».

According to K.G. Borisov (2001), the purpose of establishing WCO is to standardize and harmonize customs procedures, and its main objectives include the study of all issues related to cooperation between states in the customs sphere, research and analysis of procedural aspects of national customs systems of member states, coordination and unification in the preparation of draft conventions, agreements and recommendations, development of customs and tariff documents.

In turn, S.T. Alibekov (2012) points out that the main goals of the organization are: a) maximum harmonization and unification of customs systems; b) improvement of customs technique and customs legislation; c) development of cooperation between countries in the customs sector.

Professor K.K. Sandrovsky (2001) and Professor S.V. Kivalov (2009) define the purpose of the formation of WCO as follows: «The purpose of the WCO - is not only the creation of the executive apparatus necessary for the implementation of the life of conventions developed under the auspices of an organization specifically created for the cooperation of states on customs matters. The organization is endowed with broad powers to, as noted in the founding act, ensure the highest possible level of coherence and uniformity of their customs systems and strengthen the study of problems arising in the development and improvement of customs equipment and customs legislation».

At the same time, the text of the Declaration of the CCC on the Challenges of 2000, adopted in June 1987 (Ottawa Declaration), states that the purpose of the Convention is to: «ensure the highest possible level of coherence and uniformity of customs systems and in the course of development and improvement of customs technique and customs legislation ...», «to promote cooperation between governments on these issues, taking into account economic and technical factors related to it» (World Customs Organization, 2000).

In our opinion, the specific statement of the purpose (goals) of the Convention used in the Ottawa Declaration, as set out in the text of its Preamble, is too broad, as it also contains a description of WCO's priorities for specifying the purpose of its foundation and activity.

Having differentiated them, it is suggested that the purpose of WCO is to promote cooperation between the governments of its members (World Customs Organization, 1950). It should be noted that these are the governments of all members of the organization, not just the governments of the states that have signed the Convention establishing the CCC. 
However, each of the authors in his own way indicates not only the desired (necessary) results, the achievement of which should be aimed at the activities of the organization, but also the direct participants in the WCO customs cooperation, which leads to ambiguous characteristics of its purpose (goals) as well as to reducing the number of species differentiation of its members.

Achieving the goal of WCO necessitates the definition of its priorities, ie important issues that specify the goal and which the organization should strive to solve, because, as V. Moravetsky (1976) wrote, the essence of any organization is the activities aimed at fulfilling common tasks for its members.

It should be noted that, as in the case of the purpose (goals) of WCO, in the theory of international customs law there is no single view of the list of its tasks.

Thus, K.G. Borisov (2001) believes that one of the main tasks of WCO is to study the possibilities of customs cooperation and unification of customs practices of member states, preparation of draft international customs agreements and recommendations on the application of customs tariffs, as well as other areas of customs activity.

N.E. Buvaeva (2013) points out that WCO, as a world-class international intergovernmental organization, has broad tasks to organize international cooperation in the field of customs, in particular, the development of international customs conventions aimed at approximating the legal regulation of customs relations and recommendations for their uniform application and interpretation.

According to N.V. Zhivenko (2007), the main tasks of WCO include: improvement, simplification and unification of customs activities; improvement of customs legislation and practice of its application; strengthening the fight against international crimes by customs means.

S.T. Alibekov (2012) argues that the task of WCO is to improve the efficiency of customs administrations by promoting international customs standards.

In turn, O.V. Grebennikov (2012)considers the main tasks of WCO in one list with its functions and V.V. Mytsyk (1991), directly notes that the main tasks of WCO are defined in Art. III of the Convention on the Establishment of CCC, etc.

In our opinion, the above views of WCO activity researchers on the priorities of the organization can be considered debatable, because they do not take into account the provisions of the Preamble to the Convention on the Establishment of CCC, and some of them identify WCO's tasks with its functions.

Therefore, in view of the above, we believe that the WCO's primary objectives, which specify its purpose and which the organization should seek to solve, are as follows:

1. Ensuring the highest possible level of coordination and uniformity of the customs systems of its members;

2. Intensifying the study of problems arising in the development and improvement of customs equipment and customs legislation.

At the same time, the text of the Preamble to the Convention establishing the CCC draws attention to the fact that the achievement of WCO's specific goal, namely to promote cooperation between the governments of its members on the above issues (tasks), should be carried out not only in the interests of its members, but also : «In the interests of 
international trade, taking into account economic and technical factors related to it» (World Customs Organization, 1950).

Thus, these priority (statutory) tasks of WCO are general in nature, conditioned by its purpose and directly subordinate to it. Like the purpose of WCO, they are relatively promising, stable and permanent, subordinate to the functions of WCO.

At the same time, the WCO tasks enshrined in the Preamble to the Convention on the Establishment of CCC do not exhaust their full list, the gradual expansion of which is due to various factors. In particular, due to the emergence of tasks that did not exist at the time of signing the Convention on the Establishment of CCC, or were unrealistic (ensuring the activities of regional training centers, the use of e-learning programs and electronic data exchange systems), tasks, the formulation of which is determined by the WCO's need to respond on exacerbating various global problems of mankind (growing terrorism, overcoming economic backwardness in the world, determining the role of customs in providing assistance in dealing with natural disasters), or utilitarian tasks facing WCO during its operation (finding sponsors (donors) to finance the organization's initiatives in developing countries).

Formal approval of new WCO tasks (both for the organization as a whole and for its individual bodies) takes place through the adoption of legal acts by the WCO Council. Wellknown examples of such acts are the Ottawa Declaration of 1987, the Resolution on the Role of Customs in the 21st Century in 2008, the Resolution on the Role of Customs in Disaster Relief in 2011, and others.

For example, in pursuance of the Resolution on the Role of Customs in the 21st Century 2008, WCO is tasked with developing a new strategy in the near future that would involve:

- development of the initiative to promote the effective functioning of trade systems, simplification of the principles of international trade relations, ensuring a sufficient level of state border security;

- representing the position of the customs community at the highest level, strengthening mutually beneficial cooperation with other international organizations in both political and technical spheres (for example, with the World Trade Organization, the UN and its specialized agencies, the International Maritime Organization, the World Bank and the International Monetary Fund) to strengthen the position of customs administrations and increase the importance of WCO initiatives;

- ensuring stable institutional development of customs administrations;

- changing the position of the WCO Secretariat in the context of assisting Member States' customs administrations (World Customs Organization, 2008).

The tasks of WCO are mediated by its functions, i.e., as V. Moravetsky (1976) emphasized, the processes of the organization's activities aimed at carrying out its tasks. The task is a sample, and the function is a gradual achievement of the sample; if the task determines what the organization must achieve, the function determines how the organization operates in order to achieve the desired transformation of the sphere.

Therefore, in order to solve common tasks for the members of the organization, WCO is endowed with the following functions: 
- study of all issues related to customs cooperation, which the contracting parties have agreed to promote in accordance with the main aims (objectives and tasks) of the Convention;

- the study of the technical aspects of customs systems, as well as related economic factors, in order to offer WCO members practical means of achieving the highest possible level of coherence and uniformity;

- preparation of draft conventions and amendments thereto, as well as making recommendations for their adoption by the Governments concerned;

- development of recommendations to ensure uniform interpretation and application of conventions concluded as a result of the work of WCO as well as conventions concerning the nomenclature for classification of goods in customs tariffs and valuation of goods for customs purposes, prepared by the European Customs Union Study Group, and also the exercise for this purpose of functions which may be directly assigned to it by these conventions in accordance with their provisions;

- the development of conciliatory recommendations for the settlement of disputes concerning the interpretation and application of the conventions referred to above, in accordance with the provisions of those conventions; the parties to the dispute may agree in advance to consider the recommendations of the Council binding;

- ensuring the dissemination of information related to customs regulations and procedures;

- providing interested governments, on their own initiative or at their request, with information or advice on customs matters in accordance with the main objectives of the Convention and making recommendations in this regard;

- cooperation with other intergovernmental organizations on issues within the competence of WCO (World Customs Organization, 1950).

Acquaintance with a list of WCO functions enshrined in Art. III of the Convention on the Establishment of the CCC, allows us to conclude that from the very beginning of the organization the list was not exhaustive and remains so to this day.

\section{CONCLUSIONS}

Summarizing the above, we can reach the following conclusions on clarifying the essence of the concepts «WCO purpose», «WCO objectives», «WCO functions» and their delimitation:

1. the purpose of the WCO determines the desired (necessary) result, the achievement of which should be aimed at the activities of the organization and is to promote cooperation between the governments of its members;

2. the achievement of the goal of WCO necessitates the solution of tasks common to its members, which specify the goal and which the organization should strive to solve, namely:

- Ensuring the highest possible level of coordination and uniformity of customs systems of its members; and

- Strengthening the study of problems arising in the course of development and improvement of customs means and customs legislation; 
3. the tasks of WCO provided for in the Preamble to the Convention on the Establishment of CCC do not exhaust their full list, the gradual expansion of which takes place through the adoption of legal acts by the WCO Council;

4. WCO tasks are subordinated to WCO functions. The functions of the WCO determine how to carry out its tasks and achieve its objectives. Enshrined in Art. III of the WCO Statute, the list of functions of the international organization is proposed to be considered as inexhaustible.

Thus, despite the existing conceptual similarity of the categories «purpose», «objective» and «functions», their delimitation in the context of WCO's activities is important and necessary.

\section{RECOMMENDATIONS}

The materials of this article may be useful to WCO activity researchers, to teachers who are teaching disciplines devoted to the study of relations in which WCO participates or which are influenced by the activities of this organization, as well as to customs practitioners and subcontractors, as well as for practical employees of customs administrations and business entities that directly interact with the customs authorities on the movement of goods and commercial vehicles across customs borders.

Further research and practical elaboration of this issue remains relevant both for individual states and for the entire international community. After all, in the context of joining the subjects of international law joint efforts against various threats to humanity as a whole, including the spread of COVID-19 in the world, the essence of WCO may change significantly, which may directly affect changes in the national customs administrations of its membersstates.

\section{REFERENCES}

Alibekov, S. T. (2012). International customs law. (2nd ed.). Almaty: KazUmOiMy named after Abylai Khan, $1454 \mathrm{p}$.

Borisov, K. G. (2001). International customs law. (2nd ed.). Moscow: Publishing house of RUDN, 616 p.

Buvaeva, N. E. (2013). International customs law; ed. A. V. Zubach. Moscow: Publishing House, 376 p.

Chapa, R. T. (2020). Implementing an innovation strategy in WCO; responding to disruptive events. World Customs Journal, 14 (2), 39-61.

Customs Law of East Asia / ed. by Chia-Jui Cheng. Kluwer Law International BV, The Netherlands, 2010. xxxvii, $555 \mathrm{p}$.

Denisenko, S.I. (2015). International legal standards for simplification and harmonization of customs procedures in the field of international trade. PhD Thesis. Odessa: Nat. University «Odessa. jurid. acad.», $287 \mathrm{p}$.

Grebennikov, A. V. (2012). World Customs Organization in international customs law. Minsk:

Beltamozhservice, $64 \mathrm{p}$.

Hesketh, D. (2020). The WCO's impact to date and lessons learned: the road from Columbus to Competency. World Customs Journal, 14 (2), 99-108.

Kafeero E. (2008). Customs and trade facilitation in the East African Community (EAC). World Customs Journal. 2 (1), 63-71.

Kafeero E. (2009). Customs Law of the East African Community in light of WTO Law and the Revised Kyoto Convention PhD Thesis: Lyabuguma, Uganda, 268 p. 
Kivalov, S. V. (2009). World Customs Organization: History and Modernity. Customs, 6 (66), 3-9.

Matsudaira, T. T. (2007). Trade Facilitation, Customs and the World Customs Organization: Introduction to the WCO Trade Facilitation Instruments. Global Trade and Customs Journal, 2, 243-254.

Moravetsky, V. (1976). Functions of an international organization. Moscow: Progress, 384 p.

Mytsyk, V. V. (1991) Evolution of international legal regulation of international customs relations. Visnyk of Kyiv National University. Socio-political sciences, 4, 62-67.

Muzyka Ya. I. (2015) Legal status of the World Customs Organization PhD Thesis. Odessa: Nat. University «Odessa. jurid. acad.», $200 \mathrm{p}$

Peteva, J. (2020) The World Customs Organization as a knowledge-based organisation. World Customs Journal, 14 (2), 109-118.

Raikova, A. Yu. (2009). International legal aspects of simplification and harmonization of customs procedures (on the example of international customs conventions on ATA Carnets). PhD Thesis. Moscow: Moscow. state inst. international relations of the Ministry of Foreign Affairs of Russia, 189 p.

Sandrovsky, K. K. (2001). International customs law: textbook. (2nd ed.). Kyiv: Knowledge, KO0, 461 p. Scharf, M. P. (2007). The law of international organizations: problem and materials. (2nd ed.). Durham, NC : Carolina Academic Press, 1326 p.

Schermers, H. G., Blokker, N. M. (2011). International institutional law: unity within diversity. (5nd rev. ed.). Leiden : M. Nijhoff, 1273 p.

Weerth C. (2008). HS 2007: notes of the tariff nomenclature and the additional notes of the EC. World Customs Jour-nal. 2 (1), 111-115.

Weerth C. (2009). The Structure and Function of the World Customs Organization. Global Trade and Customs Journal. 4 (5), 131-154.

Weerth, C. (2020). The World Trade Organization and World Customs Organization key conventions and agreements (TFA, HSC, RKC): membership trends and opportunities. World Customs Journal, 14 (1), 107 126.

Wolffgang, H.-M., Dallimore, C. (2012). The World Customs Organization and its Role in the System of World Trade: An Overview. European Yearbook of International Economic Law, 3, 613-633.

World Customs Organization. (1950). Convention establishing a Customs Co-operation Council. Retrieved April 20, 2021, from http://www.wcoomd.org/en/about-us/legal-instruments/conventions.aspx

World Customs Organization. (2000). Declaration of the Council for meeting the challenges of the year 2000 - Ottawa Declaration (June 1987). Retrieved April 20, 2021, from http://www.wcoomd.org/en/aboutus/legal-instruments/declarations.aspx

World Customs Organization. (2008). Customs in the 21st century. Enabling growth and development by facilitating trade and improving border security. Retrieved April 20, 2021, from http://www.wcoomd. org/ /media/wco/public/global/pdf/topics/key-issues/customs-in-the-21st-century/annexes/annex_ii_ en.pdf?la=en

Zhivenko, N. V. (2007). International legal basis of customs regulation of foreign economic activity. PhD Thesis. Mos-cow: All-Russian Academy of Foreign Trade, 172 p. 